\title{
STRATEGIA ZARZĄDZANIA PRZEDSIĘBIORSTWEM BUDOWLANYM, ETAPY ROZWOJU I STAN WSPÓŁCZESNY
}

\author{
Roman Tracz ${ }^{\bowtie}$ \\ Wydział Budownictwa i Inżynierii Środowiska, Szkoła Główna Gospodarstwa Wiejskiego w Warszawie, Warszawa
}

\begin{abstract}
STRESZCZENIE
Artykuł ma charakter badania teoretycznego i jest poświęcony analizie aktualnego stanu strategii zarządzania przedsiębiorstwem budowlanym. Zdiagnozowano współczesny stan teorii zasobowej i etapów jej powstawania, przeanalizowano perspektywiczne kierunki rozwoju oraz porównano z innymi koncepcjami. Zaproponowano stosowanie współczesnych metod modelowania informacyjnego (BIM) oraz zintegrowanej realizacji projektu (IPD) jako kluczowych czynników innowacyjnego rozwoju przedsiębiorstw budowlanych. Zintegrowana realizacja projektu budowlanego powinna być poparta odpowiednią technologią informacyjną, która daje możliwość efektywnego wykorzystania wszystkich dostępnych zasobów informacyjnych. Wspólną dla obu koncepcji jest współpraca różnych podmiotów uczestniczących przez cały okres istnienia obiektu budowlanego (ang. life cycle assessment). Pozwala to na wdrożenie, otrzymanie i aktualizację informacji w celu zachowania i odzwierciedlenia roli każdego użytkownika.
\end{abstract}

Słowa kluczowe: teoria zasobowa, strategia przedsiębiorstwa, zdolności dynamiczne, innowacje, BIM, IPD

\section{WSTĘP}

Współczesne zarządzanie strategiczne przedsiębiorstwem budowlanym to proces gromadzenia informacji i podejmowania decyzji, który jest wspierany przez funkcje planowania, organizacji, motywacji, kontroli. Ma on charakter interdyscyplinarny. Przedmiotem zainteresowań autora są kluczowe kwestie przetrwania i rozwoju przedsiębiorstw, ze szczególnym uwzględnieniem środowiska zewnętrznego i wewnętrznego w warunkach konkurencji.

Od końca XX do początku XXI wieku wiedza i kompetencje zaczynają być ważnymi czynnikami w kształtowaniu kosztów produkcji, a innowacje odgrywają wiodącą rolę w walce przedsiębiorstwa o przewagę konkurencyjną i nowe rynki. Efektem wspomnianych czynników są zmiany warunków gospodarczych powodujące konieczność opracowania innowacyjnych metod rozwoju nowoczesnych przedsiębiorstw wykorzystujących technologie do osiągnięcia lepszych wyników.

Zdolność do wykorzystania zasobów intelektualnych i wprowadzenia rozwiązań innowacyjnych w celu zaspokojenia potrzeb ludzkich zaczyna zajmować główne miejsce w gospodarce opartej na wiedzy. Ludzka wiedza i umiejętności są ośrodkiem tworzenia wartości, które stały się bardziej widoczne w wieku informacji, w którym coraz większe znaczenie ma koncepcyjna forma pracy.

\footnotetext{
$\otimes_{\text {roman_trach@sggw.pl }}$ 
Nowe uwarunkowania gospodarki, globalizacja, Internet to tylko niektóre ze zjawisk, które prowadzą do konieczności znacznego przewartościowania strategii zarządzania w przedsiębiorstwach. Ten proces przebiega w sposób ciągły i dynamiczny. Można stwierdzić, że obecnie konkurencja między firmami rozwija się w niemal wszystkich segmentach rynku. Często konkurencyjność jest analizowana z punktu widzenia zdolności produkcji lepszych i tańszych dóbr, co jest istotnym czynnikiem dla odbiorcy produktu.

Z punktu widzenia teorii zarządzania strategicznego powstaje istotna kwestia: czy i w jakim stopniu zmiany te odzwierciedlają rzeczywistość, czy teoria nadąża za praktyką, a może wyprzedzając ją, wskazuje właściwe rozwiązania dla praktyki.

\section{MATERIA I METODY}

Od lat 60. XX wieku do początku XXI wieku budownictwo było jedną z najbardziej nieefektywnych gałęzi gospodarki. Jak wynika $z$ badań przeprowadzonych w USA (Rumane, 2015), podczas gdy w ostatnich 50 latach w budownictwie nastąpił spadek produktywności o $20 \%$, w innych gałęziach przemysłu wystąpił trend odwrotny - produktywność wzrosła przeszło dwukrotnie (rys. 1).

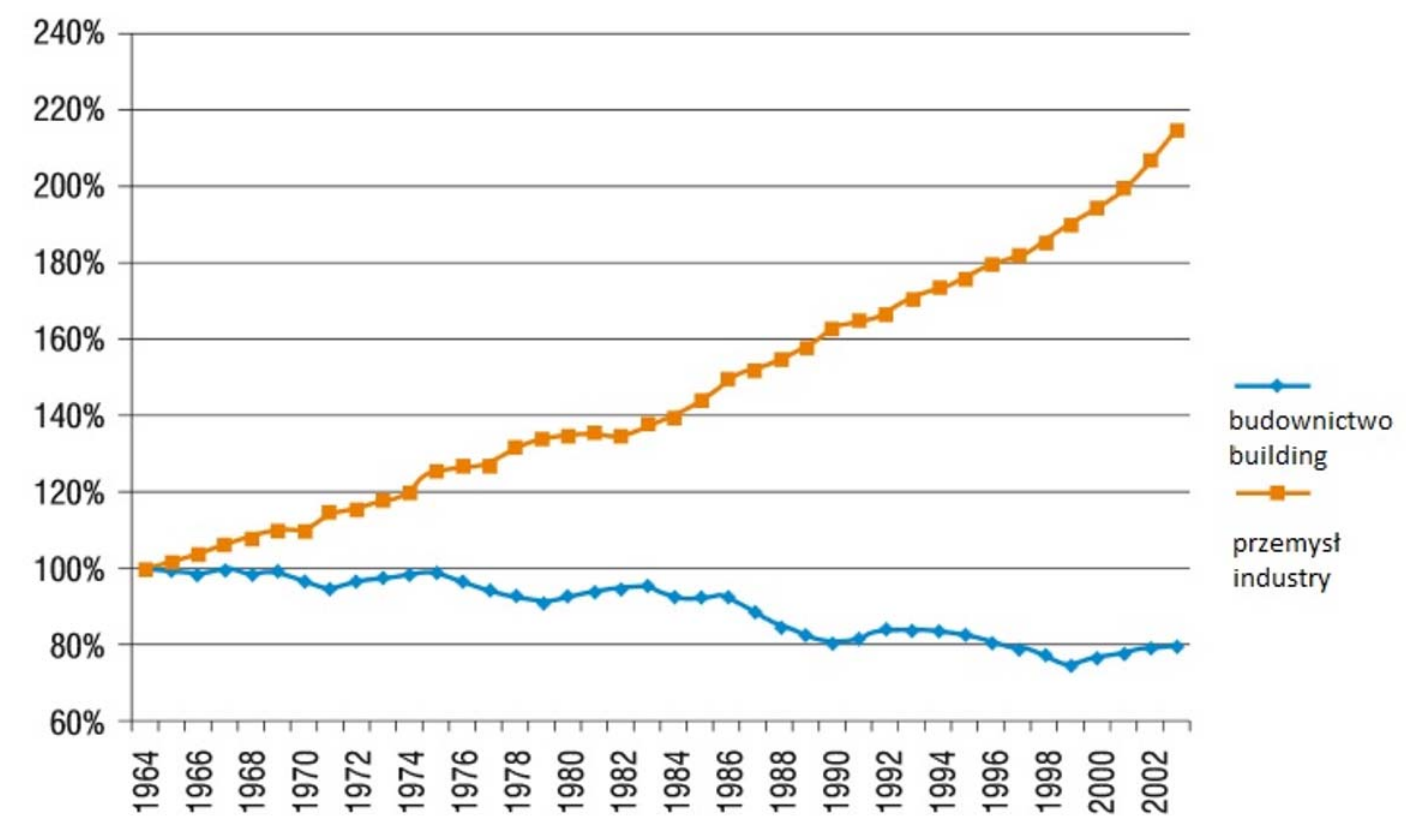

Rys. 1. Zmiany produktywności w budownictwie i przemyśle w latach 1964-2003 w USA (Rumane, 2015)

Fig. 1. Changes of the productivity in building and industry in 1964-2003 in the USA (Rumane, 2015)

Dzięki wpływowi wielu czynników sytuacja zmieniła się w okresie ostatnich 10 lat. Konserwatywna branża budowlana zmuszona do rezygnacji ze swoich tradycyjnych metod w coraz większym zakresie będzie musiała wykorzystywać nowoczesne technologie. Wprowadzenie w ostatnich latach do praktyki komputerowych metod modelowania całych kluczowych faz cyklu budowlanego i innych nowoczesnych technologii informacyjnych już zmieniło oblicze branży. W najbliższym czasie może zmienić się praktycznie nie do poznania zestaw materiałów i technologii wykorzystywanych w tej branży.

Odwołam się do doświadczenia Wielkiej Brytanii, kraju, w którym jako jednym z pierwszych w Europie zrozumiano, że nastała pora przemian w całej branży budowlanej. 
Jednym z najważniejszych dokumentów, który był przyczynkiem do zmian w sektorze budowlanym, był raport Przeglad kosztów infrastruktury brytyjskiego ministerstwa skarbu (HM Treasury, 2010). Wedle powyższego dokumentu koszt budowy infrastruktury w Wielkiej Brytanii był wówczas około $40 \%$ większy niż w porównywanych gospodarkach europejskich. Raport zawiera rzeczową diagnozę ówczesnego stanu wiedzy.

Do najważniejszych czynników wpływających na zwiększenie kosztów zaliczono problemy, które występują głównie w fazie inicjowania i planowania projektów:

- brak strategii firm wykonawczych, które działają na rynku na zasadzie zdobywania kolejnych zleceń, a nie szerszego, holistycznego spojrzenia na rynek,

- prowadzenie jednorazowych inwestycji, które nie wynikają z żadnego jasnego planu działań,

- niedostatek przejrzystości sposobu podejmowania kluczowych decyzji w fazie inicjacji projektu i podczas projektowania, a także niejasność ról i odpowiedzialności zamawiających, wykonawców i instytucji finansujących,

- zarządzanie dużymi projektami infrastrukturalnymi w taki sposób, aby zmieścić się w zakładanym budżecie, a nie uzyskać wymagany produkt za jak najniższą cenę,

- przesadne specyfikowanie wymagań, zakup produktów na zamówienie w sytuacji, w której można skorzystać z gotowych rozwiązań,

- prowadzenie procesu zamówienia w sposób, który prowadzi do wzrostu wartości ofert uzyskania w wyniku awersji zamawiających do ryzyka (przerzucanie w kontraktach zbyt wielkiego ryzyka na wykonawców),

- niedostatek inwestycji w kluczowe umiejętności firm dla zwiększenia wydajności.

Raport przewidywał, że koszty te można ograniczyć nawet o 15\%, poprzez:

- opracowanie strategicznych planów inwestycyjnych,

- wprowadzenie efektywnego sposobu zarządzania projektami,

- wymuszenie większej dyscypliny w prowadzeniu projektów poprzez zapewnienie odpowiednich wymagań oraz kosztorysów wyższej jakości,

- rozwinięcie sposobów zachęcenia do konkurencji między firmami, w szczególności poprzez poprawę procedur oceny ryzyka w różnych sposobach kontraktowania usług/zamówień,

- stworzenie warunków, które zachęcą branżę do inwestowania w zwiększenie efektywności i redukcję kosztów bezpośrednich budowy.

Według wniosków raportu HM Treasury jednym z głównych problemów w brytyjskim sektorze budowlanym był brak strategii rozwoju przedsiębiorstw budowlanych, który prowadzi do nieefektywnego sposobu zarządzania projektami oraz niedostatku inwestycji w kluczowe umiejętności firm dla zwiększenia ich wydajności itd.

Opracowując aspekty teoretyczne i metodologiczne zarządzania strategicznego przedsiębiorstwem budowlanym, warto zaznaczyć, że w działalności praktycznej menedżerowie kierują się koncepcjami systemowymi oraz wykorzystują podczas tworzenia strategii wiele narzędzi.

Z reguły w zarządzaniu strategicznym przedsiębiorstwem budowlanym są wykorzystywane cztery podejścia (rys. 2): koncepcja planowania, koncepcja projektowania, koncepcja pozycjonowania, koncepcja zasobów.

Szkoły planowania, ewolucyjna, pozycyjna i zasobowa są obecnie podstawowymi podejściami do strategii, które mają określone fundamentalne podstawy teoretyczne oraz empiryczne. Należy zauważyć, że szkoły ewolucyjna i planowania strategicznego wzajemnie się uzupełniają. Pierwsza tłumaczy genezę kwestii, a druga proponuje mechanizm zmian. Instrukcje dotyczące radzenia sobie z zagadnieniami i problemami powstającymi podczas dalszej pracy podaje szkoła pozycyjna. Szkoła zasobowa łączy w sobie różne elementy pozostałych szkół - ze szkołami planowania strategicznego i pozycyjną wspólne jest założenie, że budowa strategii wymaga jasnych menedżerskich decyzji na poziomie przedsiębiorstwa budowlanego, a ze szkołą ewolucyjną ma wspólną teorię, że realizacja strategii ma charakter planowany i etapowy, w miarę tego, jak w przedsiębiorstwie pojawiają się ważne zasoby o znaczeniu strategicznym. 


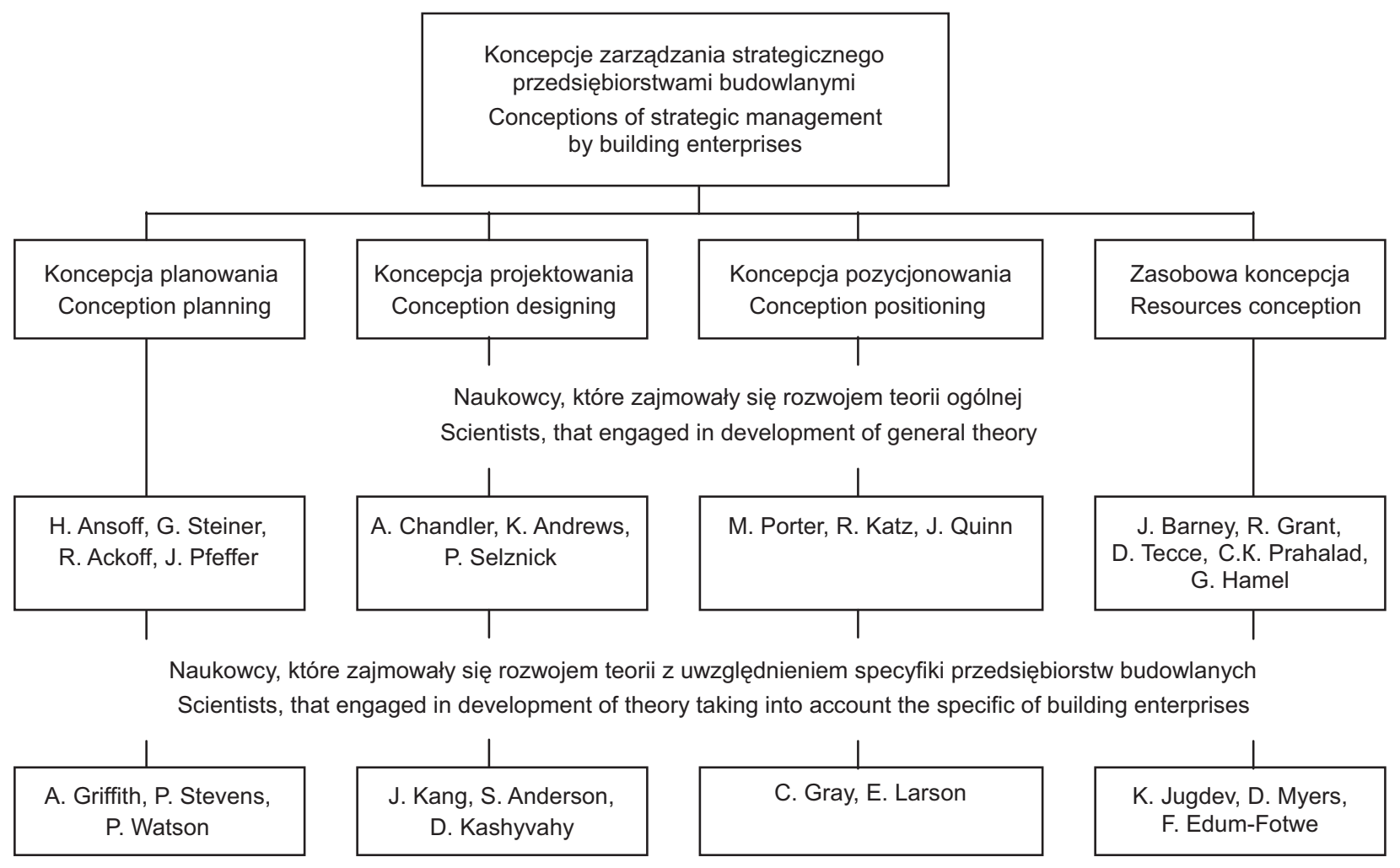

Rys. 2. Główne podejścia do zarządzania strategicznego przedsiębiorstwami budowlanymi (opracowanie własne)

Fig. 2. The basis going near a strategic management building enterprises (own elaboration)

Badania najbardziej aktualnych, światowych trendów w literaturze przedmiotu wyraźnie wskazują na opracowywanie kierunków związanych ze strategią okresu transformacji i kryzysu, z rozwojem teorii zasobów oraz $\mathrm{z}$ budową strategii wspierających kluczowe procesy biznesowe. Takie kierunki badań pozwalają uzyskać najlepsze dopasowanie prognoz i metodologii, które są z nimi związane, do potrzeb współczesnego biznesu, którego dźwignią są informacja i wiedza.

Kryzys gospodarczy, polityczny i ekonomiczny na początku XXI wieku wygenerował znaczną liczbę pytań na temat skuteczności zarządzania strategicznego w postaci wskazanej przez większość szkół strategii. Możliwość osiągnięcia w różny sposób zamierzonego wyniku strategicznego, brak jednoznacznych definicji wartości, korzystności oraz funkcji celu, a szczególnie istotna rola warunków nieprzewidzianych (Swanson, Bowen, Phillips, Gallup i Lynes, 2010), subiektywizm w budowie aksjologicznych kryteriów nie ułatwiają rozwiązania zadania związanego z przewidywaniem, jedynie wskazują na brak poczucia uniwersalizacji strategii zarządzania przedsiębiorstwem (Simon, 1982).

Ewolucja zarządzania strategicznego jest badana przez naukowców przez pryzmat dominujących w tym czasie teorii, które są pogrupowane w szkoły zarządzania strategicznego. W literaturze naukowej istnieje wiele klasyfikacji opisujących różnice, a także teorie zmian chronologicznych w myśleniu strategicznym.

Różnorodność ujęć definicyjnych strategii jest skutkiem przesunięcia punktu ciężkości na inne elementy wykorzystywane do jej opisu. Niektórzy autorzy za kluczowe dla strategii uważają wybór długofalowych celów oraz dobór określonych programów lub planów ich realizacji (K. Andrews, R. Ackoff) poprzez odpowiednią alokację zasobów (A. Chandler, D. Schendel, K.J. Hatten, E.F. Harrison). Inni autorzy podkreślają istot- 
ność działań, planów, programów lub orientacji potrzebnych do osiągnięcia określonych celów (W.F. Glueck, J.A. Pearce, R.B. Robinson, R.W. Griffin, J.B. Singh, R.F. David, C.W. Hill, G.R. Jones, R.M. Grant). Strategia jako sposób połączenia przedsiębiorstwa z otoczeniem stanowi treść kolejnej grupy definicji (R.L. Katz, R.E. Miles, C.C. Snow, H. Mintzberg, J.A.F. Stoner). Inni naukowcy koncentrują się na budowaniu przewagi konkurencyjnej i wynikach działalności firmy (M.E. Porter, J.B. Barney, E.H. Bowman, H. Singh, H. Thomas). Dla innych badaczy interesujący jest proces podejmowania decyzji dla osiągnięcia celów (G.A. Steiner, J.B. Miner, J.B. Quinn, H. Thomas, R. Whittington) i wykorzystywanych technikach podejmowania decyzji (M.O. Beverley, D. Knights, G. Morgan), a także zmianach zachodzących zarówno w otoczeniu, jak i we wnętrzu firmy (W.H. Newman, J.P. Logan, A. Ginsberg). Można także odnaleźć grupę eklektycznych ujęć strategii, integrujących wcześniej wymienione elementy (A.A. Thompson, A.J. Strickland, G. Johnson, K. Scholes, R. Whittington, R. Nag, D.C. Hambrick, M.J. Chen) (Zakrzewska-Bielawska, 2014).

Aby dokonać oceny strategii zasobów działalności przedsiębiorstwa budowlanego, warto przeanalizować proces jej tworzenia, kierunki rozwoju oraz różnice w porównaniu z podstawowymi ideami konkurencyjnych koncepcji.

Za najbardziej popularną klasyfikację strategii uważany jest podział opracowany przez Mintzberga, Ahlstranda i Lampela (2009), w którym wyróżnionych jest 10 szkół myślenia strategicznego (projektowania, planowania, pozycjonowania, przedsiębiorczości, wiedzy, wykształcenia, władzy, kultury organizacyjnej, środowiska zewnętrznego, konfiguracji).

Główną kwestią teorii zarządzania strategicznego jest poszukiwanie trwałej przewagi konkurencyjnej przedsiębiorstw. Podział źródeł przewag na wewnętrzne i zewnętrzne był jednym z głównych kierunków tej teorii. Dyskusja ma na celu wyjaśnienie względnego znaczenia pozycjonowania przedsiębiorstwa na rynku oraz obecności unikatowych zasobów i zdolności organizacyjnych, czyli innymi słowy, zidentyfikowanie roli różnic między strukturą przemysłu (rynku) oraz między odrębnymi przedsiębiorstwami.

Największy wpływ na teoretyków koncepcji zasobów miała praca Penrose zatytułowana Teoria rozwoju firm. W przeciwieństwie do konwencjonalnych w tym czasie poglądów ekonomicznych, autorka zauważyła przewagę potencjału zasobów w przedsiębiorstwie. Ona pierwsza zauważyła zależność przewagi konkurencyjnej od zdolności organizacyjnych przedsiębiorstw, która w jej interpretacji ,jest w istocie zbiorem zasobów, których stosowanie jest zorganizowane w ramach systemu administracyjnego" (Penrose, 1959). Oprócz tego definicja zasobów dziedzicznych bezpośrednio wskazuje na jedną z głównych przyczyn trudności kopiowania struktur ze względu na wyjątkowość każdego przedsiębiorstwa.

Większość naukowców za początek współczesnych badań w ramach teorii zasobów uznaje publikację Wernerfelta zatytułowaną Interpretacja zasobów przedsiębiorstwa, która według swojej terminologii była początkiem nowego kierunku teorii zarządzania strategicznego (Wernerfelt, 1984). Główną tezą koncepcji zasobów jest to, że wszystkie przedsiębiorstwa w rzeczywistości są różne, gdy każde z nich ma unikalne zasoby i umiejętności, które będąc źródłem czynszów ekonomicznych, kształtują ich przewagę konkurencyjną.

Kolejnym etapem zainteresowania ze strony środowisk naukowych oraz biznesowych koncepcją zasobów była publikacja Prahalada i Hamela pod tytułem Kluczowe kompetencje korporacji (1990). Biorąc pod uwagę doświadczenia najlepszych korporacji świata tego czasu, Prahalad i Hamel doszli do wniosku, że prawdziwe źródła przewagi konkurencyjnej zależą od zdolności kierownictwa do konsolidacji rozproszonych technologii i umiejętności produkcyjnych, które umożliwiają indywidualnym przedsiębiorstwom szybkie dostosowanie do zmieniających się uwarunkowań rynkowych.

Przejrzystość w definiowaniu podstawowych pojęć jakiejkolwiek teorii jest ważnym czynnikiem motywującym ich pomyślny rozwój. Mimo że koncepcja zasobów zarządzania strategicznego istnieje już od dekady, nadal nie ma ogólnie przyjętych interpretacji pojęć zasobów i zdolności, przy czym w początkowych definicjach zasobów i zdolności zwolennicy koncepcji zasobów zbliżyli się do ostatecznej interpretacji (Grant, 1991). 
Istnieją dwie przyjęte interpretacje definicji w tej kwestii. Kryterium rozróżnienia polega na specyficznym rozumieniu różnicy między pojęciami zasobów i zdolności przedstawionym na rysunku 3.

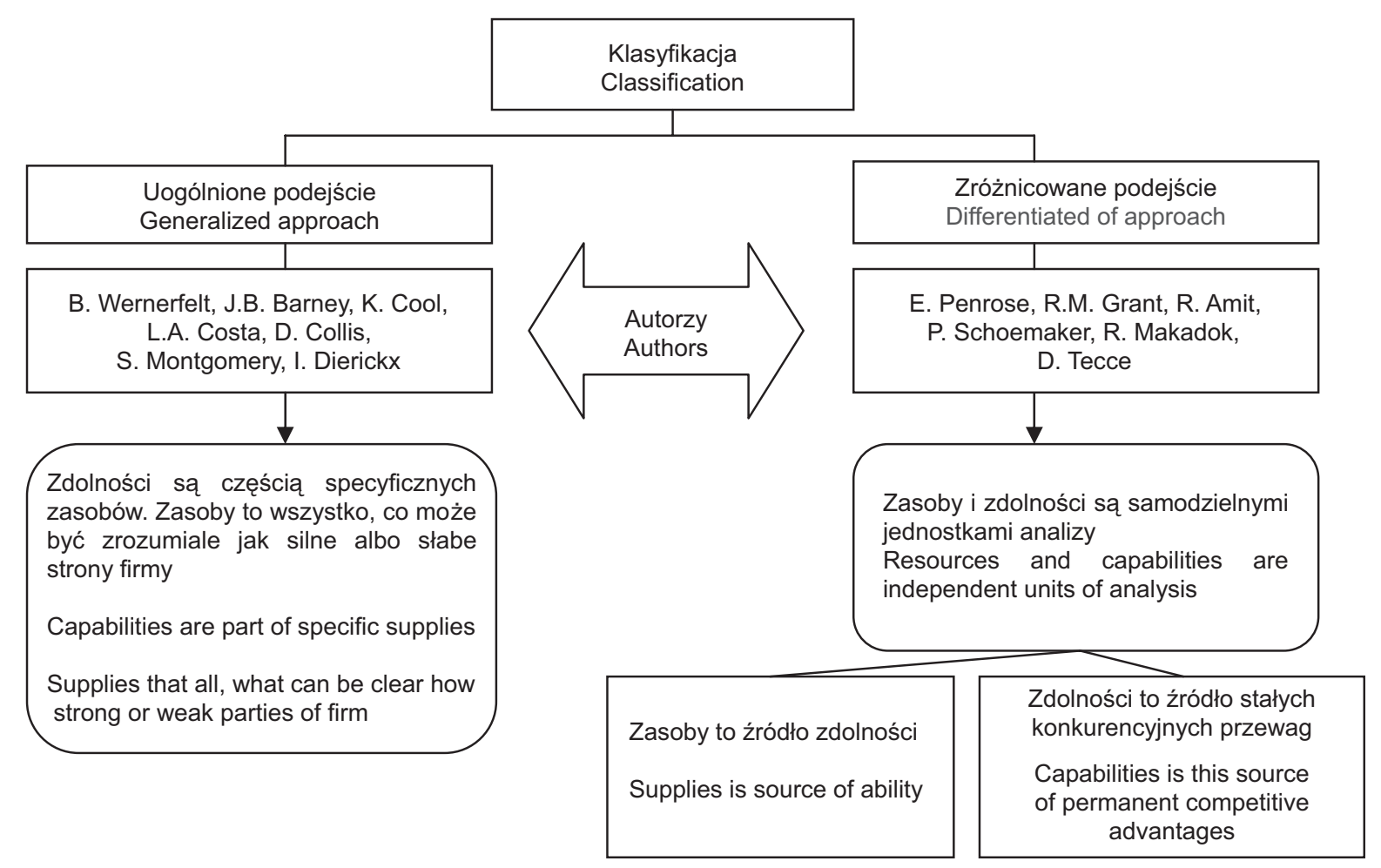

Rys. 3. Różnica między pojęciami zasobów i zdolności (opracowanie własne)

Fig. 3. Differentiation of concepts resources and ability (own elaboration)

Podejście do zasobów podkreśla wyjątkowość każdego przedsiębiorstwa, wskazując, że kopiowanie i naśladowanie innych przedsiębiorstw nie pomoże w osiągnięciu rentowności, warto zaś koncentrować się na wykorzystaniu różnic i unikalnych zalet własnego przedsiębiorstwa. W teorii zasobów istotne są zakup i akumulacja oraz zdolność do wykorzystania zasobów w celu otrzymania innych zasobów, ich oryginalnej transformacji w produkty i usługi oraz wprowadzenie tych produktów i usług na rynek (Krupski, 2012). Strategia ta jednak często nie jest wystarczająca do osiągnięcia trwałej przewagi konkurencyjnej przedsiębiorstwa budowlanego. Wygrać w rywalizacji na globalnym rynku mogą przedsiębiorstwa, które szybko reagują na zmiany oraz sprawnie wprowadzają „elastyczne” innowacje produktowe wraz ze zdolnością efektywnego koordynowania i przenoszenia kompetencji wewnętrznych i zewnętrznych.

Tecce, Pisano i Shuen wprowadzili pojęcie dynamicznych zdolności, które definiują jako „potencjał przedsiębiorstwa w integracji, stworzeniu i rekonfiguracji wewnętrznych i zewnętrznych kompetencji w celu dopasowania do środowiska, które szybko się zmienia. Otóż, zdolności dynamiczne odzwierciedlają potencjał organizacji w osiągnięciu korzyści innowacyjnej” (Tecce, Pisano i Shuen, 1997).

Nelson twierdzi, że różnice organizacyjne, a szczególnie różnice w zdolności do tworzenia innowacji i uzyskania zysku od działalności innowacyjnej, a nie różnice w technologii produkcji są źródłem stabilnych długoterminowych przewag przedsiębiorstwa (Nelson, 1991). 


\section{WYNIKI}

Przedstawiciele biznesu stawiają wiele pytań dotyczących koncepcji zdolności dynamicznych. Oczywiście w szybko zmieniającym się środowisku unikalność zasobów może być szybko zanegowana. Jedynym skutecznym mechanizmem realizacji przewagi rynkowej na podstawie zdolności dynamicznych jest ciągłe odnawianie organizacyjne przedsiębiorstwa budowlanego poprzez innowacje.

Naukowcy różnią się w rozważaniach dotyczących głównych tendencji, lecz wniosek, że konieczność przemian (zdolność do ich występowania jako imperatywny wymóg naszego czasu) jest ogólnie przyjęty. Jak zaznacza Raspopow, „we współczesnej konkurencyjnej walce w pierwszej kolejności walka idzie nie o posiadanie zasobów, materialnych wartości, a o zdolność do innowacji” (Raspopow, 2009).

Zmiany zaistniałe na początku XXI wieku są związane przede wszystkim z szybkim tempem rozwoju techniki i technologii, postępem cywilizacyjnym, koncentracją na innowacjach i zachowaniach przedsiębiorczych, procesami globalizacji i większą intensywnością konkurencji, przyjmującą często postać hiperkonkurencji. Spowodowały one pojawienie się kolejnych podejść do strategii. Wśród nich należy wymienić podejście innowacyjno-przedsiębiorcze, podejście relacyjne oraz podejście według paradoksów.

Pierwsze z nich zakłada, że logika biznesu jest budowana wokół innowacji i aktywności cechującej osoby przedsiębiorcze i określa strategię jako „zespół działań umożliwiających kreowanie zmian o charakterze innowacyjnym, generującym wartość z punktu widzenia interesariuszy” w celu uzyskania renty schumpeteriańskiej, powstającej z tytułu innowacji, i renty austriackiej, powstającej w wyniku zarządzania zasobami umożliwiającymi eksploatację nowych możliwości stwarzanych przez otoczenie (Niemczyk, 2013).

Obecnie wzrosła liczba uczestników procesu budowlanego oraz liczba kanałów informacyjnych, a także zwiększył się ich wpływ na wyniki działalności. W związku z tym bardzo istotne staje się rozwiązanie problemu optymizacji komunikacyjnego obszaru. Niektórzy uczeni proponują, aby w kierowaniu przedsiębiorstwem budowlanym zastosować podejście sieciowe, którego podstawą metodyczną jest koncepcja relacji (Melehin i Ismailowa, 2004). Koncepcja relacji bazuje na wymianie potoków z uwzględnieniem logistycznych zasad minimalizacji kosztów na przechodzenie materialnych i finansowych zasobów, potoków siły roboczej, usług, informacji.

Stosunkowo niedawno dodano nowe wymaganie - zrównoważonego rozwoju (Wall, 2010). Pojęcie zrównoważonego rozwoju stanowi przesłankę, która przenika obszary badawczy i gospodarczy, i można sądzić, że będzie wyrażało megatrend XXI wieku.

Obiekt budowlany powinien być zaprojektowany, wzniesiony, użytkowany i rozebrany zgodnie z wymaganiami zrównoważonego rozwoju. Oznacza to nowe wyzwania w zakresie projektowania konstrukcji z uwzględnieniem trwałości, a także w obszarze inżynieryjnych metod utrzymania, modernizacji i naprawy konstrukcji (Czarnecki i Łukowski, 2010). Można oczekiwać, że odtąd dokumentacja projektowa będzie zawierać nie tylko wskazania w zakresie użytkowania i utrzymania obiektu, ale także odnośnie rozbiórki, recyklingu i powtórnego użycia materiałów. Konsekwencją przyjęcia zrównoważonego rozwoju jako głównej wytycznej postępu jest powstanie nowej przestrzeni badawczej.

Zrównoważony rozwój to zadanie budowania wielu rodzajów równowagi na różnych poziomach. Najogólniejsze ujęcie dotyczy społeczeństwa, środowiska i ekonomii. W odniesieniu do budownictwa oznacza to całościowe ujęcie oddziaływania na środowisko w ciągu pełnego cyklu istnienia obiektu budowlanego (ang. life cycle assessment, LCA - analiza w pełnym cyklu istnienia).

Równocześnie z realizacją idei zrównoważonego rozwoju powinny być powiązane koncepcje innowacyjności i relacyjna. Najlepszym rozwiązaniem dla połączenia tych zadań jest nowoczesna koncepcja zarządzania modelowaniem informacyjnym w budownictwie, znana jako BIM (ang. building information modelling). 
Koncepcja BIM, definiowana jako metodyka zarządzania kluczowymi informacjami w postaci cyfrowej na przestrzeni wszystkich faz istnienia budynku, jest uznawana za nowy paradygmat komputerowo wspomaganego projektowania (CAD) w budownictwie (Succar, 2009).

Zastosowanie koncepcji BIM jest również wskazywane jako element pozwalający na wdrożenie w budownictwie koncepcji zintegrowanej realizacji projektu IPD (ang. integrated project delivery), sformułowanej przez Amerykański Instytut Architektów (AIA), wymagającej pełnego wykorzystania wiedzy i zdolności wszystkich podmiotów uczestniczących w inwestycji budowlanej na każdym z etapów jej prowadzenia w celu optymalizacji jej efektów (AIA, 2007).

Jednym z głównych źródeł problemów w budownictwie jest oddzielenie różnych etapów realizacji projektu jeden od drugiego (projektowanie, budownictwo, eksploatacja). Kiedy projektowanie nie występuje jako jednoczesny proces realizacji, nie można mówić o efektywności, a tym bardziej o innowacyjności całego przedsięwzięcia, a obecnie na brak współpracy narzekają zarówno architekci, projektanci, jak i wykonawcy. Sposobem na rozwiązanie tych problemów jest współpraca, czyli zintegrowanie wszystkich funkcji w jeden proces - IPD.

Moim zdaniem najlepiej istotę koncepcji modelowania informacyjnego, która łączy w sobie innowacyjność, zrównoważony rozwój i koncepcje relacyjne w budownictwie, ujęto w raporcie Building SMART International (http://buildingsmart.pl/bimpl.html).

Building information modelling jest procesem twórczym generowania i wykorzystania danych o budowli, jej projektowania, budowy i eksploatacji w trakcie pełnego cyklu funkcjonowania. BIM pozwala, aby wszyscy zainteresowani uczestnicy inwestycji mieli dostęp do tych samych informacji, w tym samym czasie, za pośrednictwem interoperacyjnych platform technologicznych.

Przedsiębiorstwo budowlane ma działać na styku gospodarki i nauki, prowadzić aktywną działalność badawczo-rozwojową (B\&R), być źródłem tworzenia nowej wiedzy, wynalazków i innowacji. Powinno ono łączyć w sobie cechy przedsiębiorstwa innowacyjnego i przedsiębiorstwa bazującego na know-how i B\&R, co wpisuje się w założenia przyjętej strategii Europe 2020 (EC, 2010).

Przedsiębiorstwo budowlane powinno być nowoczesne, w osiągnięciu czego pomoże mu wiedza oraz umiejętność jej praktycznego zastosowania w zakresie teorii strategicznego zarządzania zasobami. Koncentracja na zasobach, zwłaszcza niematerialnych (rozwój wiedzy jako zasobu, zdolność do eksperymentowania i tworzenia innowacji), pozwala bowiem przedsiębiorstwu budowlanemu utrzymać stałą przewagę konkurencyjną.

\section{PODSUMOWANIE}

Zarządzanie strategiczne przedsiębiorstwem budowlanym realizuje się poprzez specyfikę procesu budowlanego. Istota ekonomiczna procesu budowlanego odzwierciedla koszty na jego realizację, które z kolei są podzielone na jednorazowe i trwałe. W związku z tym istota ekonomiczna budownictwa wskazuje na duży koszt materiałów oraz złożoność procesu technologicznego, który wraz z wyjątkowością każdego projektu budowlanego powoduje konieczność specjalnego podejścia do zarządzania.

Biorąc powyższe pod uwagę, najbardziej odpowiednią strategią zarządzania w obecnych warunkach ekonomicznych, moim zdaniem, jest koncepcja podejścia „zasobów” z uwzględnieniem dynamicznych zmian w środowisku.

Osiągnięcie celu strategicznego przedsiębiorstwa budowlanego dostrzegam w ogólnej interpretacji teoretycznego podejścia zasobów, biorąc pod uwagę dynamiczny charakter rynku - realizacja strategii rozwoju przedsiębiorstwa na podstawie osiągnięcia długoterminowych przewag konkurencyjnych, które tworzą unikalny organizacyjny i ekonomiczny model przedsiębiorstwa.

Dalsze badania powinny koncentrować się na ocenie perspektyw oraz ewentualnych skutków wynikających $\mathrm{z}$ absorpcji koncepcji zrównoważonego rozwoju, podejścia innowacyjnego i koncepcji relacyjnej w komputerowym modelowaniu parametrycznym procesu budowlanego opracowanego według koncepcji BIM i IPD. 
Tracz, R. (2017). Strategia zarządzania przedsiębiorstwem budowlanym, etapy rozwoju i stan współczesny. Acta Sci. Pol. Architectura, 16 (4), 93-102. doi: 10.22630/ASPA.2017.16.4.09.

\title{
PIŚMIENNICTWO
}

The American Institute of Architects, AIA (2007). Integrated Project Delivery: A Guide. Sacramento, CA: AIA California Council.

Czarnecki, L. i Łukowski, P. (2010). Wdrażanie normy PN-EN 1504 - dostosowania w Polsce. Materiały Budowlane, 2 , $2-5$.

European Commission, EC (2010). Europe 2020. A strategy for smart, sustainable and inclusive growth. Brussels.

Grant, R. M. (1991). The resource-based theory of competitive advantage: Implication for strategy formulation, California Management Review, 3 (33), 114-135.

HM Treasury (2010). Infrastructure Cost Review. Main Report. Pobrano z lokalizacji: https//www.gov.uk/government/ uploads/system/uploads/attachment_data/file/192588/cost_review_main211210.pdf (dostęp: 14.02.2017).

Krupski, R. (2012). Rozwój szkoły zasobów zarządzania strategicznego. Przegląd Organizacji, 4, 4-16.

Melehin, W. B. i Ismailowa, S. T. (2004). Sieciowe organizacyjne struktury kierowania budowlanym przedsiębiorstwem. Gospodarka Budownictwa, 7, 14-23.

Mintzberg, H., Ahlstrand, B. i Lampel, J. (2009). Strategy safari. Your complete guide through the wilds of strategic management. United Kingdom, London: Prentice Hall.

Nelson, R. (1991). Why Do Firms Differ, and How Does It Matter? Strategic Management Journal, 12, 61-74.

Niemczyk, J. (2013). Strategia. W: Od planu do sieci (strony 159-166). Wrocław: Wydawnictwo Uniwersytetu Ekonomicznego.

Penrose, E. (1959). The theory of growth of the firm. New York: Oxford Univeristy Press.

Prahalad, C. K. \& Hamel, G. (1990). The core competence of the corporation. Harvard Business Review, 68, 79-91.

Raspopow, W. M. (2009). Kierowanie przemianami. Moskwa: Magister.

Rumane, A. (2015). Handbook of Construction Management: Scope, Schedule, and Cost Control. Boca Raton, Florida: CRC Press.

Simon, H. A. (1982). Models of bounded rationality. Cambridge, MA: MIT Press.

Succar, B. (2009). Building information modelling framework: A research and delivery foundation industry stakeholders. Automation in Construction, 18, 357-375.

Swanson, M., Bowen, P., Phillips, A. W., Gallup, D. i Lynes, D. (2010). Contingency Planning Guide for Federal Information Systems. Washington: NIST Special Publication.

Tecce, D., Pisano, G. i Shuen A. (1997). Dynamic Capabilities and Strategic Management. Strategic Management Journal, 18 (7), 509-533.

Wall, S. (2010). Budownictwo spełniające wymagania rozwoju zrównoważonego w nowych dokumentach UE. Biuletyn $I T B, 1$.

Wernerfelt, B. (1984). A resource-based view of the firm. Strategic Management Journal, 5, 171-180.

Zakrzewska-Bielawska, A. (2014). Ewolucja szkół strategii: przegląd głównych podejść i koncepcji. Zarządzanie strategiczne. Rozwój koncepcji i metod. Prace Naukowe Wałbrzyskiej Wyższej Szkoły Zarządzania i Przedsiębiorczości, 27, 9-29.

\section{MANAGEMENT STRATEGY OF ENTERPRISE IN THE FIELD OF BUILDING, DEVELOPMENT PHASES AND CURRENT STATUS}

\begin{abstract}
The article is a theoretical study and deals with the analysis of the current state of building companies' management strategy. Investigated the state of the resource theory, the process of its formation, promising developments and differences on the basic ideas of competing concepts. Rapid implementation of building information modeling (BIM) and integrated project delivery (IPD) of all key stages of the construction cycle and other advanced information technology (IT) have greatly changed the face of the industry. It is determined that the integrated construction project delivery should be supported by the corresponding
\end{abstract}


Tracz, R. (2017). Strategia zarządzania przedsiębiorstwem budowlanym, etapy rozwoju i stan współczesny. Acta Sci. Pol. Architectura, 16 (4), 93-102. doi: 10.22630/ASPA.2017.16.4.09.

information technology and unimpeded access to information. Concepts of BIM and IPD provide collaboration of various stakeholders during certain phases of the facility life cycle (life cycle assessment), which allows the implementation, acquisition and updating of information in order to maintain and reflect the role of each user.

Key words: resource theory, strategy of enterprise, dynamic capabilities, innovations, BIM, IPD 